\title{
Productivity Growth, Efficiency Change, \& Technical Progress of a Corporate Sector in Bangladesh: A Malmquist Output Productivity Index Approach
}

\author{
Nasir Uddin ${ }^{1}$ \\ ${ }^{1}$ Department of Business Administration, Yokohama National University, Yokohama, Japan \\ Correspondence: Nasir Uddin, Department of Business Administration, Yokohama National University, \\ Tokiwadai 79-4, Hodogaya-Ku, Yokohama 240-8501, Japan. Tel: 81-45-339-3659. E-mail: \\ uddin-nasir-xc@ynu.jp
}

Received: May 8, 2015

Accepted: May 22, 2015

Online Published: July 25, 2015

doi:10.5539/ijef.v7n8p240

URL: http://dx.doi.org/10.5539/ijef.v7n8p240

\begin{abstract}
The purpose of this study is to estimate the Malmquist productivity change index for a corporate sector in Bangladesh. In addition to estimating the Malmquist productivity change index, the reasons of productivity change are also investigated. The study shows that productivity is increased by 1.3 percent per year over the period 2006-2012. This growth is due to increase in efficiency by 4.1 percent per year and decline in the catching up by 2.7 percent per year. A study of leverage ratios of the productivity growth and the productivity declined industry shows that there is a mismatch between the leverage ratios of the two groups. Moreover, a relationship study shows that the Malmquist productivity change index or its components and the traditional measures of the corporate performance present different aspects of corporate performance. The study suggests using the Malmquist productivity change index as a proxy of corporate performance when checking the effect of leverage on performance and effect of performance on leverage. Finally, the study ends with the suggestions for the managers for the productivity improvements.
\end{abstract}

Keywords: malmquist productivity index, technical efficiency, technical progress, proxy for corporate performance, leverage and efficiency, DEA-like linear programming problem

\section{Introduction}

The corporate sectors of Bangladesh are growing substantially and playing substantial role in the growing economy of Bangladesh. To grow more efficiently, it is important for a firm to study its productivity and to take measures, if necessary, to improve the productivity of the firm. In addition, the productivity analysis is of interest to management, regulators, employees, and governments. According to Kendrick (1993), productivity is a very important issue at personal, company, industry and national level. Hence, productivity study is an utmost important activity to the interest groups. Under the importance, the broad objective of this study is to analyze the productivity of a corporate sector of Bangladesh.

Like many other countries, the corporate productivity or performances are analyzed by using financial ratios in Bangladesh. The variables used in the past literature and reported in the annual reports of the firms to represent the firm performance are return on equity, earning per share, return on sales, return per employee, return on total assets, and operating cash flow to total assets etc. However, those ratios are calculated based on one input, hence represent partial productivity and should not be a measure of corporate performance. Because corporate performance is the result of many inputs: capital, labor, material, energy, and other inputs. This study uses a newer technique called Malmquist productivity index to measure the productivity change index of the firms of a corporate sector of Bangladesh.

The broad objective of this study is to estimate the productivity growth, efficiency change and technical progress index of the firms in the sample of the corporate sector in Bangladesh. In consistent with the broad objective, the specific objectives are: (i) to estimate the Malmquist productivity index of the firms in the sample of the corporate sector in Bangladesh. (ii) to identify the sources of the productivity change: efficiency change or technical progress so that measures for the productivity improvement can be taken, (iii) to check the relationship between the financial leverage and Malmquist productivity index of the productivity growth industry and the 
productivity declined industry, (iv) to determine the correlation coefficients between the Malmquist productivity Index and its components and other traditional measures of corporate performance in order to check whether the two type indicators express the same aspects of the corporate performance, and (v) to measure and analyse the partial productivity.

This study reports and suggests using a productivity change ratio called Malmquist productivity change index as the measure of corporate performance for four reasons. Firstly, productivity analysis by using the Malmquist productivity index provides the reasons of productivity change and the magnitudes account for the reasons. In other words, what is the reason of the productivity change: technical efficiency change or technical change? And how much of the total change is because of the change in technical efficiency or technical change? Secondly, whereas the other types of productivity are estimated by using either one input or one output, the Malmquist productivity analysis can take into account multiple inputs and outputs to calculate the productivity change index. Thirdly, there is no need of any behavioral assumption like profit maximization or cost minimization. Finally, do not need price data of the input and outputs. For the above advantages, this study uses the Malmquist productivity index to analyze the productivity of the corporate sectors in Bangladesh.

In order to achieve the objectives, this study uses data from 14 pharmaceuticals companies listed at Dhaka Stock Exchange Limited-the main stock exchange of Bangladesh for seven years: 2006-2012 and The data is collected from the annual reports of the companies reserved at Bangladesh Securities and Exchange Commission library, Dhaka Stock Exchange Limited library, Chittagong Stock Exchange Limited library and University of Liberal Arts library.

This study claims three academic contributions. Firstly, the study provides new and original empirical evidence from the data of pharmaceuticals sector in Bangladesh. Secondly, this research showed that the Malmquist productivity change index and its components and the traditional measures of corporate performance present different aspects of corporate performance. Thirdly, this study proposes to use Malmquist productivity change index and its components as the proxy of corporate performance and to check the effect of leverage on performance and effect of performance on leverage.

The rest of the study is organized as follows: the section 2 discusses about the productivity management and the related ideas: concepts, importance, sources, management, and measures; the section 3 deals with the concept of the models of the study, and allied matters: specification of the model, basic and pictorial presentation of the output distance functions, Malmquist index, the Malmquist productivity index and its decomposition, returns to scale, and data envelopment analysis (DEA); the section 4 discusses about the data of the study and their characteristics, the section 5 presents the results of the study and their analyses and the section 6 presents conclusion of the study and the future research directions.

\section{Productivity}

The word "productivity" was, probably, first introduced by a French Mathematician-Quesnay in a piece of writing in 1766 (Sumanth, 1998). Unfortunately, the words productivity and efficiency are used interchangeably by many people. But they are different in exact definition. Increase in efficiency does not pledge increase in productivity and increase in efficiency is a necessary condition to increase in productivity, but not sufficient condition. Efficiency is defined as actual output divided by standard output whereas productivity is equal to actual output divided by input consumed. As formula, efficiency and productivity are defined as equation (1).

$$
\text { Productivity }=\frac{\text { Actual Output }}{\text { Inputs Consumed }} \quad \text { Efficiency }=\frac{\text { Actual Output }}{\text { Standard Output }}
$$

\subsection{Importance of Productivity}

Increase in productivity is expected in all levels-national, industrial, company and personal (Kendrick, 1993). At personal level, increase in personal productivity results in increase in organizational productivity and the person's living standard. At national level, higher productivity causes in higher economic and national growth. At company level, higher productivity at company level ensures lower per unit costs and price, higher profitability, and higher competitive position in the market. At industrial level, higher productivity at industrial level strengthens the position of the industrial sector in the home and abroad markets. Thus productivity management is very important to the all concerns.

\subsection{Sources of Productivity}

Productivity growth can be from one of the four sources: new technology \& methodologies, energy utilization, investment and attitudes (Smith, 1993). Introducing new technology or methodology or up-gradation of the technology or methodology can be a source of the productivity growth and introducing or up-gradation generally 
requires the investments. Another source of the productivity growth may by use of the energy. The use of energy may be from any source, even may be from human mind. The attitudes of employee, employer and management may be the important sources of the productivity growth. From wherever productivity comes, subject to performing standard quality, social responsibility, and performing other management responsibilities, are most welcome by the decision making units.

\subsection{Productivity Management}

There are four steps in the productivity management (Sumanth, 1998): measurement, evaluation, planning and improvement. The first step of the productivity management is the productivity Measurement. The productivity is measured from one of the three points of the views. Firstly, the present level of productivity is computed and compared with the productivity of the other decision maker for the necessary actions. Secondly, estimating productivity of one period and compared with the other period of the same decision maker. Finally, the productivity of a decision making unit can be studied including many DMUs and periods. This procedure is used in this study to study the productivity of the sample firms. The relevant concern should follow the steps in the continuous manner after every period.

\subsection{Productivity Measures}

\subsubsection{Productivity Ratios}

To generate the outputs, firms uses the inputs, and the inputs are processed to generate the outputs in the production process. In other words, the conversion cycle is the inputs to the process, from the process to the outputs (Figure 1). The productivity ratio measures the productivity of this transformation process: how much/many outputs are produce by using the inputs. The higher ratio means the higher productivity and the lower ratio means the lower productivity. The productivity is defined as equation (2).

$$
\text { Productivity }=\frac{\text { Output }}{\text { Input }}
$$

The figure-1 shows the input-output process.

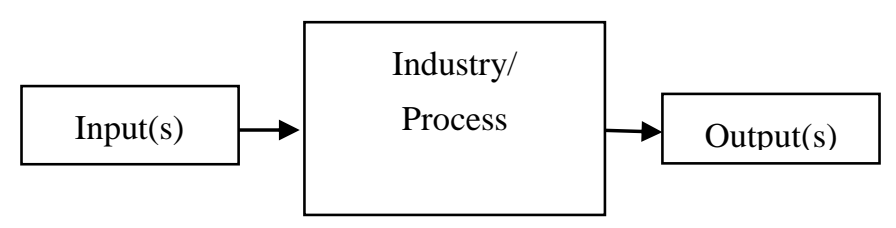

Figure 1. Input-output process

In order to compute the productivity ratio of the firm, the input and output variables data are compulsory. The productivity analysis is a data sensitive technique. The use of more inputs and outputs variables, makes the decision making unit more unique and increase the possibility of comparison with the less numbers of DMUs. As a result, measuring the number of inputs and outputs variables as reasonable as possible is very important. In general, the input variables are capital which may be physical, financial or inventory capital, labour which may be number of labours, number of labour hours, or labour costs: wages \& salary, energy costs which may be, oil, gasoline, or other energy costs, and materials costs. The output variables may be gross outputs, net output, may be products, or services.

Based on the number of inputs considered in the productivity calculation, productivity measurement can be divided into three groups: partial productivity, total factor productivity, and total productivity. The three types of the productivity are discussed briefly here. Partial productivity: Partial productivity (PP) is the quotient obtained by dividing an output by an input of the production. In this regard, we can say capital productivity, labour productivity, material productivity, energy productivity or other input productivity. The advantage of the using and estimating partial productivity index as the index to present corporate performance is that it is easy to calculate, interpret and understand. The disadvantage is that it is overstated. For the better understanding, assume, $\mathrm{O}=$ output, $\mathrm{L}=$ labour, $\mathrm{C}=$ capital, $\mathrm{E}=$ energy, $\mathrm{M}=$ materials, $\mathrm{m}=$ other inputs. Symbolically, partial productivity (PP) is defined as equation (3).

$$
P P=\frac{O}{L(\text { or } M, C, E, m)}
$$

Total factor productivity (TFP) is the quotient of dividing the output by the capital and the labour. This measure 
is a better measure than the partial productivity as this measures consider capital- labour substitution. The disadvantage is that it is difficult to calculate, understand and interpret compare to the partial productivity. Symbolically, TFP is defined as equation (4).

$$
T F P=\frac{O}{L+C}
$$

Total productivity (TP) is the quotient of dividing the output by the all inputs used in the production process. The advantage of the total factor productivity is that it considers all of the inputs used in the production process and the disadvantage is that it is difficult to calculate, understand and interpret. Symbolically, TP is defined as equation (5).

$$
T P=\frac{O}{L+M+C+E+m}
$$

Based on the objective of the productivity analysis: output maximization, input maximization or both together (output maximization and input minimization), the productivity analysis can be divided into three: output oriented productivity analysis, input oriented productivity analysis and additive productivity analysis. In an output oriented analysis, the objective is to increase in outputs as much as possible for a given level of inputs. In an input oriented analysis, the objective is decrease in inputs as much as possible by keeping outputs as constant. In the additive productivity analysis, the inputs are decreased as many units as possible and the outputs are increased as many units as possible. For the details in productivity management see Christopher (1993), Sumanth, (1998), Belasco (1990).

\section{The Concept of the Model}

\subsection{Specification of the Model}

Determining input and output variables in order to estimate the productivity of the sample firms are one of the biggest challenges of this study because of very limited empirical research in this field. However, Margaritis and Psillaki (2010) used two inputs: labour and capital as input variables and value added as output variables, where the input variables- labour is measured by total labour and capital is measured by fixed assets. The output variables-value added is defined as net profit plus depreciation and labour cost: wages plus salaries plus benefits. The first part (net profit plus depreciation) is the return to capital (capital, land, and assets) and second component (wages plus salaries plus benefits) is the return to labour. In addition, Berger and Bonaccorsi (2006) used total equity to total assets and return on equity as inputs and output variables respectively. Lin, Liu, and Chu (2005) used assets and equity as inputs variables and operating revenue and net income as output variables in order to assess efficiency of the Taiwan's shipping industry.

Data envelopment analysis is a data sensitive technique. Using more number of inputs and outputs variables make the DMUs unique and less possibility of being compared with the more numbers of best practice branches. As a result, as the number of inputs and outputs variables increases, the possibility of being efficient increases and vice-versa. In addition, sample size variables should be substantially more than number of outputs times number of inputs. Mostafa (2007) indicated that sample size should be more than three times of bigger between number of inputs and number of outputs.

In order to select the inputs and outputs variables for this study, this study considered all of the input and output variables available from the literature survey (Table 1). From the literature survey, seven variables are available as input variables and four variables as output variables. A correlation coefficient analysis is conducted in order to check the multi-colinearity and reduce the number of the variables.

Table 1. Inputs and outputs variables

\begin{tabular}{llll}
\hline & List of inputs variables & & List of outputs variables \\
\hline - & Salary and wages (= labour) & - & Value added (= EBIT + dep. + wages \& salary) \\
- & Fixed assets (= capital) & - & Return on equity \\
- & Total assets & - Operating revenue (= sales) \\
- Total equity to total assets & - Net income (= net profit) \\
- Equity & & \\
- Debts & \\
- Total expenses & \\
\hline
\end{tabular}

Source: Literature Survey. 
Table 2 shows the correlation coefficients of the all possible pairs of the input and output variables. The coefficients show that total fixed assets are strongly correlated with total debt $(0.84)$, total equity (0.96), and total assets (0.97). Among these four variables, total fixed assets is selected as one of the input variables. The variables: wages \& salary and total expenses are strongly positively correlated $(0.90)$. Between these two variables, wages and salary is accepted as the second input variable. Finally, for the analysis sample, total fixed assets, and wages and salary are selected as input variables. In the case of output variables, sales or revenue and net profit is strongly positively correlated (0.94). From these two variables, net profit is selected as an output variable. And the second output variable is value added. Thus the input variables are total fixed assets and wages and salary and the output variables are net profit and value added.

Table 2. Correlation matrix for the input and output variables

\begin{tabular}{|c|c|c|c|c|c|c|c|c|c|c|c|}
\hline & $T D$ & $T E$ & $T A$ & $T F A$ & TE/TA & $W \& S$ & Texp & $S=R$ & $N P$ & $V A$ & $R O E$ \\
\hline Total Debt & 1.00 & & & & & & & & & & \\
\hline Total Equity & 0.82 & 1.00 & & & & & & & & & \\
\hline Total Asset & 0.91 & 0.96 & 1.00 & & & & & & & & \\
\hline Total Fixed Asset & 0.84 & 0.96 & 0.97 & 1.00 & & & & & & & \\
\hline$T E / T A$ & 0.22 & 0.44 & 0.35 & 0.36 & 1.00 & & & & & & \\
\hline Wages and salary & 0.80 & 0.79 & 0.83 & 0.76 & 0.28 & 1.00 & & & & & \\
\hline Total Expenses & 0.78 & 0.76 & 0.82 & 0.75 & 0.29 & 0.90 & 1.00 & & & & \\
\hline Sales $=$ Revenue & 0.80 & 0.81 & 0.86 & 0.78 & 0.29 & 0.88 & 0.93 & 1.00 & & & \\
\hline Net Profit & 0.71 & 0.83 & 0.84 & 0.81 & 0.33 & 0.80 & 0.86 & 0.94 & 1.00 & & \\
\hline Value Added & 0.40 & 0.56 & 0.54 & 0.55 & 0.23 & 0.51 & 0.57 & 0.63 & 0.67 & 1.00 & \\
\hline$R O E$ & -0.18 & -0.23 & -0.20 & -0.21 & -0.48 & -0.09 & -0.08 & -0.07 & -0.08 & -0.06 & 1.00 \\
\hline
\end{tabular}

Source: Author's calculations.

The ratio variables do not follow convex to the origin characteristics, hence: total equity to total assets is not considered as input variable and for the same reasons return on equity is not considered as output variable in this study. In addition, a sensitivity analysis is conducted by using an alternative combination of variables-total assets and total expenses as input variables and sales or revenue and value added as output variables. The sensitivity analysis has produced the similar results to the main analyses.

At the time of the analyses, it is assumed that for an input variable "less is better" and for an output variable "more is better". The Figure 2 presents that industries in the study uses fixed assets and salary \& wages as the input variables and produces net income and value added as the output variables.

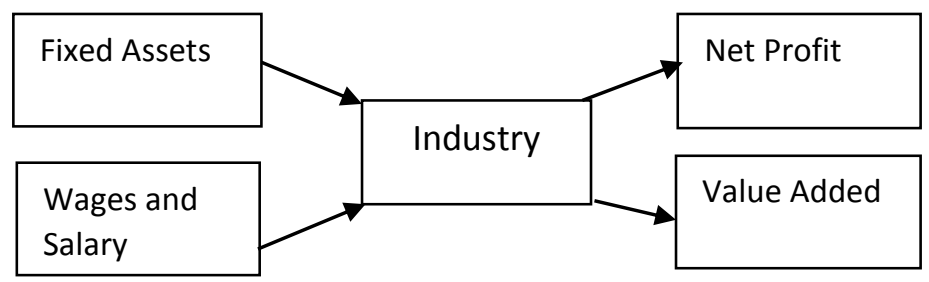

Figure 2. Firm input and outputs

\subsection{Output Distance Function}

The Malmquist Productivity Index can be constructed by one of the two ways: by using the ratios or by using the distance functions. Mlima (1999) constructed the Malmquist productivity index as a ratio of the Malmquist output-quantity index to the Malmquist input-quantity index. As an alternative, the Malmquist productivity index can be constructed by using the distance functions. The use of the distance functions enables consideration of multiple inputs and multiple outputs. In addition, there is no need of the profit maximization or cost minimization assumption when the Malmquist productivity index is constructed by using the distance functions. This study determines the Malmquist productivity index by using the distance functions.

Malmquist productivity index are divided into two: Malmquist input-productivity index and Malmquist output-productivity index. The Malmquist input productivity index is constructed based on the input distance 
functions and the Malmquist output productivity index is constructed based on the output distance functions. An input distance function describes possible maximum decrease in inputs for a given outputs and an output distance function describes possible maximum increase in outputs for a given inputs level. The value of a distance function is varying between 0 and 1 . In this study, Malmquist output productivity index is constructed.

In order to define the distance function, consider, a sample of $\mathrm{n}$ DMUs and a production technology that by using $x^{t}$ input producing $y^{t}$ output in the time period $\mathrm{t}=1 \ldots \mathrm{T}$. For considering multiple inputs and outputs, the inputs and the outputs vectors are considered by using inputs, $x^{t}\left(x_{1}^{t},---, x_{n}^{t}\right)$ the firms produces outputs, $y^{t}\left(y_{1}^{t},-, y_{m}^{t}\right)$ in the time period $\mathrm{t}=1 \ldots \mathrm{T}$. Assume, $\mathrm{P}^{\mathrm{t}}$ is the output set. Now, in the set builder form, the output set is:

$$
\mathrm{P}^{\mathrm{t}}(\mathrm{x})=\left\{y^{t} / x^{t}: x^{t} \text { can produce } y^{t} \text { at time } \mathrm{t}\right\} \text { where, } \mathrm{t}=1 \ldots \mathrm{T}
$$

Shepherd (1970) distance function that is used for the Malmquist output productivity index is as follows:

$$
D^{t}(y, x)=\min \left\{\delta \in(0,1]:(y / \delta) \in P^{t}(x)\right\} \quad \mathrm{t}=1 \ldots \mathrm{T}
$$

The value of the distance function is less than or equal of one i.e., $0 \leq \mathrm{D}(\mathrm{y} \mathrm{x}) \leq 1$ when $\mathrm{y}$ is in the output possibility set, i.e. $\mathrm{y} \in \mathrm{P}(\mathrm{x})$. The value of the distance function is equal to one, i.e. $\mathrm{D}(\mathrm{y} \mathrm{x})=1$ when $\mathrm{y}$ is on the frontier line and the value of the distance function is less than one, i.e. $\mathrm{D}(\mathrm{y} \mathrm{x})<1$ when y belongs in the other area of production possibility set except on the frontier line. If the value of the distance function is one, the DMUs efficient and otherwise not efficient.

The following Figure 3 is a pictorial presentation of the output possibility set and the distance functions for the firm using one input and producing two outputs.

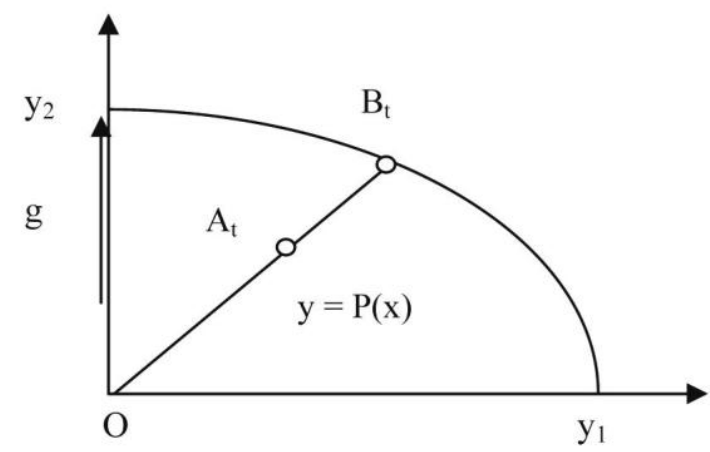

Figure 3. Output possibility set and distance functions

Figure 3 presents a production point and the production possibility frontier of the output- $\mathrm{y}_{1}$ and $\mathrm{y}_{2} . \mathrm{D}(\mathrm{y} \mathrm{x})$ indicates the output distance covered by the decision making unit from the production point $(\mathrm{O})$ to the frontier $\left(B_{t}\right)$. The inverse of the $D(y x)$ indicates the proportional increase in the present output $\left(A_{t}\right)$ to reach at the frontier $\left(\mathrm{B}_{\mathrm{t}}\right)$. By using figure-3, at $A_{t}: D^{t}\left(y^{t} x^{t}\right)=\frac{O A_{t}}{O B_{t}}<1$, and at $B_{t}: D^{t}\left(y^{t} x^{t}\right)=\frac{O B_{t}}{O B_{t}}=1$. The firm producing output at $A_{t}$ is inefficient as the point is under the frontier curve. On the other hand, the firm producing at $B_{t}$ point is efficient as the point is on the respective frontier point. To be efficient, the proportional increase of the present output level $\left(\mathrm{A}_{\mathrm{t}}\right)$ to reach at frontier lever $\left(\mathrm{B}_{\mathrm{t}}\right)$ is $\frac{O B^{t}}{O A^{t}}$.

Figure-4 shows a production point and a frontier at time $t$ and the production point and the frontier at time $(t+1)$. By using the firms' outputs production points and the frontiers, the distance functions are estimated as follows.

$D^{t}\left(y^{t}, x^{t}\right)=\frac{O A_{t}}{O B_{t}}, D^{t}\left(y^{t+1}, x^{t+1}\right)=\frac{O A_{t+1}}{O B_{t}}, D^{t+1}\left(y^{t}, x^{t}\right)=\frac{O A_{t}}{O B_{t+1}}, D^{t+1}\left(y^{t+1}, x^{t+1}\right)=\frac{O A_{t+1}}{O B_{t+1}}$. By using the four distance functions, the Malmquist productivity change index is constructed. 


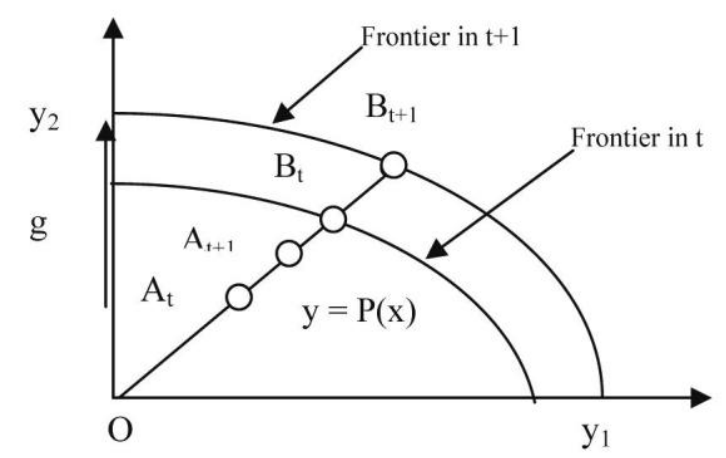

Figure 4. Distance functions and productivity indices

\subsection{Malmquist Index}

Malmquist (1953) proposed to compare the inputs of one period to the inputs of another period in terms of the maximum factor to reduce the inputs of one period subject to the production of the same outputs. This idea is known as Malmquist input index. Later, based on the Malmquist input index, the Malmquist output index is also developed by a researcher.

\subsection{Malmquist Productivity Index and Its Decomposition}

The Malmquist productivity index is used to discover the productivity difference between the two firms or one firm over the two periods of time. Malmquist productivity index is the geometric mean of the Malmquist index at the period $t$ and $t+1$. There are two Malmquist productivity indices: input-oriented Malmquist productivity index and output-oriented Malmquist productivity index. An input-oriented Malmquist productivity index is constructed by using input distance functions those describes maximum reduction in inputs by keeping outputs constant and an output-oriented Malmquist productivity index is constructed by using output distance functions those describe in maximum increase in output by keeping inputs constant. In this study, Malmquist output productivity indices are studied.

According to Caves, Christensen and Diewert (1982), the output based Malmquist productivity index between the period $t$ and $(t+1)$ is as equation (6).

$$
\operatorname{MPI}_{0}^{t,}{ }^{t+1}\left(y^{t}, y^{t+1}, x^{t}, x^{t+1}\right)=\sqrt{\left[\frac{D^{t}\left(y^{t+1}, x^{t+1}\right)}{D^{t}\left(y^{t}, x^{t}\right)} \times \frac{D^{t+1}\left(y^{t+1}, x^{t+1}\right)}{D^{t+1}\left(y^{t}, x^{t}\right)}\right]}
$$

Where the notation MPI denotes the Malmquist productivity index between the two periods. The superscript (t, $\mathrm{t}+1$ ) denotes the time periods and the subscript (o) denotes the orientation. The notation D denotes the distance function. Malmquist productivity index is the geometric mean of the two Malmquist index at the period $t$ and $t+1$. The first ratio under the square root is the Malmquist output index at time $\mathrm{t}\left(M I_{o}^{t}\right)$ which measures changes in the output from period $t$ to period $(\mathrm{t}+1)$ by using period $\mathrm{t}$ frontier as the benchmark and The second ratio under the square root $\left(M I_{o}^{t+1}\right)$ is the Malmquist output index at time $(t+1)$ which measures changes in the output from period $t$ to period $(t+1)$ by using period $(t+1)$ frontier as the benchmark. In the case of output oriented Malmquist productivity index, the index is equal to zero (MPI=0) indicates no productivity change, the Malmquist productivity index is less than one (MPI $<1)$ indicates productivity decline and the Malmquist productivity index is greater than one (MPI>1) indicates productivity growth.

By rearranging the equation (6), Färe et al. (1989) proposed the Malmquist productivity index as a product of efficiency change and technical change as equation (7).

$$
M P I_{0}^{t}{ }^{t+1}\left(y^{t}, y^{t+1}, x^{t}, x^{t+1}\right)=\frac{D^{t+1}\left(y^{t+1}, x^{t+1}\right)}{D^{t}\left(y^{t}, x^{t}\right)} \sqrt{\left[\frac{D^{t}\left(y^{t}, x^{t}\right)}{D^{t+1}\left(y^{t}, x^{t}\right)} \times \frac{D^{t}\left(y^{t+1}, x^{t+1}\right)}{D^{t+1}\left(y^{t+1}, x^{t+1}\right)}\right]}
$$

In equation (7), the first term in front of the square root is the ratio of the two distance functions measures Farrell (1957) technical efficiency change (Effch) from the period $t$ to the period $(t+1)$. The second term measures technological progress (Techch) from the period $t$ to the period $(t+1)$. In other words, the second term, TC, measures the shift in the frontier. The term Farrell technical efficiency is greater than, equal to, or less than one (Effch $(>1,=1,<1)$ ) indicates that the firm is closer to frontier, no change, decline in productivity. The second term, Techch, is greater than, equal to, or less than one (Techch $(>1,=1,<1)$ ) indicates that the technological best practice has increased, unchanged, declined. 
The Malmquist productivity index of firm-A is illustrated by using the following figure-5, considering one input one output case, assuming constant returns to scale and the equation (7). Grifell-Tatje and Lovell (1997) argued to assume constant returns to scale while estimating Malmquist productivity index as Malmquist productivity index may not capture the resulting gains or losses from scale effect while variable returns to scale is assumed. The hidden reasons are the nature of firm level and the aggregate data.

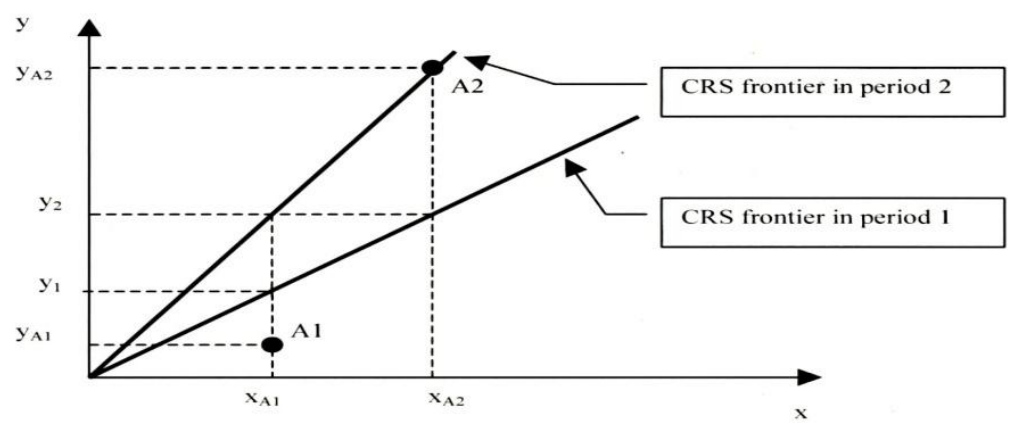

Figure 5. Malmquist productivity index

Source: Kirikal (2005), Kirikal Modified from Coelli, Rao, and Battese (1998).

In the Figure 5, the firm A produces output $\mathrm{y}$ by using input $\mathrm{x}$. The firm produces at $\mathrm{A} 1$ at time period $\mathrm{t}$ and at $\mathrm{A} 2$ at time period $(t+1)$. Firm A is inefficient at time $t$, as the firm is producing at A1, under the frontier line-CRS1. However, the firm A is efficient at time $(\mathrm{t}+1)$ and producing at A2, on the frontier-CRS2. The frontier is shifted upward indicates technical advancement/progress. The technical progress includes two components: a time component and a technological component. By using the Figure 5 and the equation (7), the Malmquist productivity index is as equation (8).

$$
M_{1,2}\left(y_{A 1}, y_{A 2}, x_{A 1}, x_{A 2}\right)=\frac{y_{A 2} / y_{A 2} 2}{y_{A 1} y_{1}}\left[\frac{y_{A 1} / y_{1}}{y_{A 1} / y_{2}} x \frac{y_{A 2} / y_{2}}{y_{A 2} y_{A 2}}\right]^{1 / 2}
$$

The Figure 5 shows that Malmquist productivity index of firm A is greater than 1 (MPI>1) which means growth in productivity. The sources and their magnitude to the Malmquist productivity index reflected in the efficiency change (Effch) ratio and technical progress (Techch) ratio. The efficiency change in firm A also greater than 1 $($ Effch $>1)$ which indicates increase in efficiency. The technical change is also greater than 1 (Techch > 1), upward ship, indicates technological progress.

A Malmquist Productivity index is calculated for the adjacent period by using the four distance functions: $D^{t}\left(y^{t}, x^{t}\right), D^{t}\left(y^{t+1}, x^{t+1}\right), D^{t+1}\left(y^{t+1}, x^{t+1}\right)$, and $D^{t+1}\left(y^{t}, x^{t}\right)$. There are many techniques to calculate the value of a distance function. The techniques available for calculating the values of the distance functions can be grouped in two broad categories: mathematical programming and econometric analysis. However, most widely used technique is the linear programming problem. Färe et al. (1994) developed DEA-friendly Malmquist productivity index. This study applies DEA-like distance functions to estimate the Malmquist productivity index.

The relationship among the Malmquist productivity change index, efficiency change, technical change, pure efficiency change, and scale efficiency change are described in the equation (9).

$$
\text { MI }=\text { Effch } * \text { Techch }=\text { Pech } * \text { Sech } * \text { Techch }
$$

MI or Tfpch - Malmquist Productivity Index;

Effch - efficiency change;

Techch - technical change;

Pech - pure efficiency change;

Sech - scale efficiency change.

Malmquist productivity index is also known as Malmquist productivity change index, Malmquist total factor productivity change index. 


\subsection{Constant and Variable Returns to Scale}

An important issue in productivity analysis is returns to scale properties of the production technology. The two most frequently returns to scale properties assumed in productivity analysis are constant returns to scale (Charnes, Cooper, \& Rhodes, 1978) and variable returns to scale (Banker, Charnes, \& Cooper, 1984). According to constant returns to scale, output will increase according to the increase in the input. For instance, if input is increased by 100 percent then output will also increase by 100 percent. On the other hand, in the case of variable returns to scale, when input increases, output increases at first and then decreases according to scale size. In figure-6, according to constant returns to scale, only the decision making unit B is efficient. However, according to variable returns to scale, all the points: A, B, C, and D, are efficient.

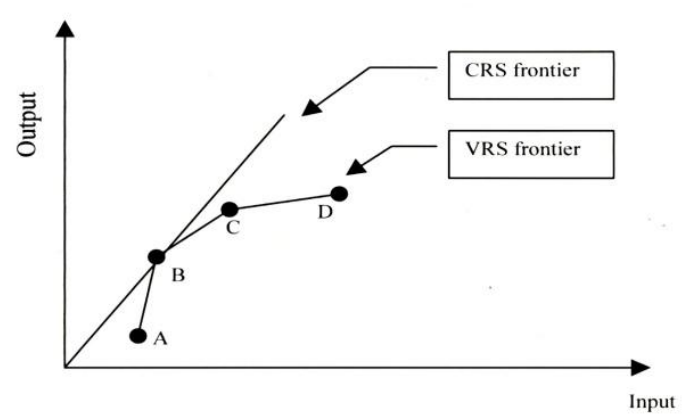

Figure 6. Constant and variable returns to scale

Source: Kirikal (2005), Kirikal Modified from Färe, Grosskopf, \& Lovell (1994).

Malmquist productivity analysis can be conducted based on the assumption-production technology follows constant returns to scale or variables returns to scale. However, this study is based on the assumption that production technology follows constant returns to scale. By using one-input, one-output example, Grifell-Tatje and Lovell (1997) showed that total factor productivity is not measured correctly when it is assumed that production technology follows variable returns to scale. This happens because of nature of firm level and aggregate data. Consequently, Malmquist productivity analysis is conducted assuming production technology follows constant return to scale.

\subsection{Data Envelopment Analysis}

Data envelopment analysis is a linear program based program developed and proposed by Charnes, Cooper, \& Rhodes (1978) to measure the efficiency of the DMUs those use the similar type of inputs and produce the similar type of outputs. The proposed model is based on the assumption of constant returns to scale and input orientation. The model forms a pair-wise non-linear efficient frontier and DMUs are compared with the frontier to determine the efficiency of the DMUs. However, model based on the various types of returns to scale and orientations are also developed later. Among the models developed later, Banker, Charnes, \& Cooper (1984) is the most popular model. However, this study is based on the assumption that production technology follows constant returns because of practible-ness of firm-level and aggregate data.

A Malmquist productivity index for a fair of adjacent period is constructed based on a set of the four distance functions: $D^{t}\left(y^{t}, x^{t}\right), D^{t}\left(y^{t+1}, x^{t+1}\right), D^{t+1}\left(y^{t+1}, x^{t+1}\right)$, and $D^{t+1}\left(y^{t}, x^{t}\right)$. We should solve total $\mathrm{n}$ sets for $\mathrm{n}$ sample DMUS. There are many econometric and mathematical methods to estimate the values of the distance functions. However, DEA-Like linear programming problems are used to estimate the values of the distance functions in this study. The following a set of four linear programming problems-output-oriented CRS envelopment model are formulated and solved to construct the Malmquist productivity index.

(a) By comparing $y^{t}$ with the frontier at time t, i. e., determining $D^{t}\left(y^{t}, x^{t}\right)$.

$$
\left[D^{t}\left(y^{t}, x^{t}\right)\right]^{-1}=\operatorname{Max} D
$$

subject to 


$$
\begin{gathered}
\sum_{j=1}^{n} \lambda_{j} x_{j}^{t} \leq x^{t} \\
\sum_{j=1}^{n} \lambda_{j} y_{j}^{t} \geq D y^{t} \\
\lambda_{j} \geq 0, j=1, \ldots \ldots . n
\end{gathered}
$$

(b) By comparing $y^{t+1}$ with the frontier at time t, i. e., determining $D^{t+1}\left(y^{t+1}, x^{t+1}\right)$.

$$
\left[D^{t}\left(y^{t+1}, x^{t+1}\right)\right]^{-1}=\operatorname{Max} D
$$

subject to

$$
\begin{gathered}
\sum_{j=1}^{n} \lambda_{j} x_{j}^{t} \leq x^{t+1} \\
\sum_{j=1}^{n} \lambda_{j} y_{j}^{t} \geq D y^{t+1} \\
\lambda_{j} \geq 0, j=1, \ldots \ldots . n
\end{gathered}
$$

(c) By comparing $y^{t+1}$ with the frontier at time $\mathrm{t}+1$, i. e., determining $D^{t+1}\left(y^{t+1}, x^{t+1}\right)$.

$$
\left[D^{t+1}\left(y^{t+1}, x^{t+1}\right)\right]^{-1}=\operatorname{Max} D
$$

subject to

$$
\begin{aligned}
& \sum_{j=1}^{n} \lambda_{j} x_{j}^{t+1} \leq x^{t+1} \\
& \sum_{j=1}^{n} \lambda_{j} y_{j}^{t+1} \geq D y^{t+1} \\
& \lambda_{j} \geq 0, j=1, \ldots \ldots . n
\end{aligned}
$$

(d) By comparing $y^{t}$ with the frontier at time $\mathrm{t}+1$, i. e., determining $D^{t+1}\left(y^{t+1}, x^{t+1}\right)$.

$$
\left[D^{t+1}\left(y^{t}, x^{t}\right)\right]^{-1}=\operatorname{Max} D
$$

subject to

$$
\begin{gathered}
\sum_{j=1}^{n} \lambda_{j} x_{j}^{t+1} \leq x^{t} \\
\sum_{j=1}^{n} \lambda_{j} y_{j}^{t+1} \geq D y^{t} \\
\lambda_{j} \geq 0, j=1, \ldots \ldots . n
\end{gathered}
$$

Where, $x_{j}^{t}=\left(x_{1 j}^{t}, \ldots ., x_{m j}^{t}\right)$ is the inputs vector, $y_{j}^{t}=\left(y_{1 j}^{t}, \ldots ., y_{s j}^{t}\right)$ is the output vector and $\mathrm{t}=1, \ldots . \mathrm{T}$. Where superscript denotes time period and subscript denotes DMU identity. $\lambda_{j}$ is the weight given to the DMU, $1 \leq \mathrm{D}$ $\leq \infty$ is proportional increase in the outputs keeping the inputs constant. $0 \leq 1 / \mathrm{D}(=\delta) \leq 1$ is a technical efficiency score.

\section{Results}

\subsection{Summary Information on the Input and Output Variables}

Table-3 shows the descriptive statistics of the input variable-total fixed assets. The mean fixed assets is stable over the period whereas maximum fixed assets is decreasing during the period and the minimum fixed assets is increasing. These trends mean that total fixed assets of the industries are moving toward a commo size. Table 4 presents descriptive statistics of input variable-wages and salary. The arithmetic mean, maximum and minimum all are substantially increasing. One reason of this increase is increase in salary and wages. Another reason is the increase in total staffs. 
Table 3. Descriptive statistics of input variable total fixed asset

\begin{tabular}{clll}
\hline Year & \multicolumn{1}{c}{ Mean } & \multicolumn{1}{c}{ Max } & \multicolumn{1}{c}{ Min } \\
\hline 2006 & 1273685450 & 8537119221 & 26723011 \\
2007 & 1495122703 & 9029643482 & 28031685 \\
2008 & 1928558516 & 11957773787 & 28870115 \\
2009 & 770078631 & 3587051489 & 26478542 \\
2010 & 2432564224 & 24722574397 & 20770800 \\
2011 & 1143238371 & 4495085038 & 33709167 \\
2012 & 1259616149 & 5406012268 & 37837094 \\
\hline
\end{tabular}

Source: Author's calculations.

Table 4. Descriptive statistics of input variable wages and salary

\begin{tabular}{cccc}
\hline Year & Mean & \multicolumn{1}{c}{ Max } & Min \\
\hline 2006 & 134894014 & 466494403 & 3821498 \\
2007 & 191164379 & 560972744 & 4464036 \\
2008 & 207015139 & 673231385 & 5364662 \\
2009 & 244398839 & 785490027 & 6441241 \\
2010 & 290264456 & 904506477 & 6464411 \\
2011 & 354664611 & 1023522927 & 7559213 \\
2012 & 370281942 & 1127001587 & 8735929 \\
\hline
\end{tabular}

Source: Author's calculations.

The descriptive statistics of the output variable-net profit are presented in the Table 5. The arithmetic mean, maximum and minimum all are increasing- may be a sign of productivity growth.

Table 5. Descriptive statistics of output variable net profit

\begin{tabular}{cccc}
\hline Year & Mean & Max & Min \\
\hline 2006 & 166226674 & 1165864616 & -17122000 \\
2007 & 188864268 & 1303242840 & -35567404 \\
2008 & 284815650 & 1381863093 & 6347155 \\
2009 & 347574362 & 1890052929 & 4371801 \\
2010 & 390443028 & 2087871791 & 4993767 \\
2011 & 461920435 & 2532054550 & 7040504 \\
2012 & 493661116 & 2897710641 & 5806652 \\
\hline
\end{tabular}

Source: Author's calculations.

Table 6 presents the descriptive statistics of the output variable-value added. The arithmetic mean, maximum value, and minimum value all are increasing. The increasing trend may be because of increasing in productivity growth. In the Malmquist productivity analysis, the impact of four inputs will be considered simultaneously and will be summarized by an index called Malmquist productivity change index.

Table 6. Descriptive statistics of output variable value added

\begin{tabular}{clll}
\hline Year & \multicolumn{1}{c}{ Mean } & \multicolumn{1}{c}{ Max } & \multicolumn{1}{c}{ Min } \\
\hline 2006 & 440023759 & 2195138366 & 14660452 \\
2007 & 515338621 & 2744107950 & 19743957 \\
2008 & 635347923 & 2733603888 & 22331885 \\
2009 & 770078631 & 3587051489 & 26478542 \\
2010 & 2432564224 & 24722574397 & 20770800 \\
2011 & 1143238371 & 4495085038 & 33709167 \\
2012 & 1259616149 & 5406012268 & 37837094 \\
\hline
\end{tabular}

Source: Author's calculations. 


\subsection{Malmquist Productivity Change Index Summary of Annual Means}

Table 7 summarizes the evolution of the productivity growth in the sector. The table shows that productivity is increased by 1.3 percent on a geometric average during the period 2006-2012, a total of 9.1 percent for the period. The growth is mainly due to increase in the technical efficiency by 4.1 percent per year, 28.7 percent in total for the period and decline in the catching up by 2.7 percent per year, 18.9 percent in total for the period. The main reason for the lower average annual productivity growth is the decline in the productivity by 12.9 percent in the period 2006-7, 12.7 percent in the period 2008-9 and 3.1 percent in the period 2011-2.

Table 7. Malmquist productivity change index summary of annual means

\begin{tabular}{lcccccc}
\hline Years & $\begin{array}{c}\text { No. of } \\
\text { Firms }\end{array}$ & $\begin{array}{c}\text { Malmquist TFP } \\
\text { Index (Tfpch) }\end{array}$ & $\begin{array}{c}\text { Technical Efficiency } \\
\text { Change (Effch) }\end{array}$ & $\begin{array}{c}\text { Technological } \\
\text { Change (Techch) }\end{array}$ & $\begin{array}{c}\text { Pure Technical } \\
\text { Change (Pech) }\end{array}$ & $\begin{array}{c}\text { Scale Efficiency } \\
\text { Change (Sech) }\end{array}$ \\
\hline $2006-7$ & 14 & 0.871 & 0.935 & 0.931 & 0.996 & 0.939 \\
$2007-8$ & 14 & 1.268 & 1.181 & 1.074 & 1.080 & 1.093 \\
$2008-9$ & 14 & 0.873 & 1.177 & 0.741 & 1.096 & 1.074 \\
$2009-0$ & 14 & 1.145 & 0.546 & 2.100 & 0.687 & 0.794 \\
$2010-1$ & 14 & 1.008 & 1.582 & 0.637 & 1.406 & 1.125 \\
$2011-2$ & 14 & 0.969 & 1.136 & 0.853 & 1.084 & 1.048 \\
\hline \multicolumn{2}{l}{ Geometric Mean } & 1.013 & 1.041 & 0.973 & 1.036 & 1.005 \\
\hline
\end{tabular}

Source: Author's calculations.

Note. All indexes are geometric averages.

More specifically, the table shows decrease, increase, decrease, increase, unchanged and decline in the productivity during the periods respectively. The table shows that the productivity is increased in the year 2007-8 by 26.8 percent which is mainly due to increase in technical efficiency-18.1 percent and partly due to increase in technological progress-7.4 percent. Later, in the year 2009-10, the technological progress happened by 110 percent and the technical efficiency is declined by 45 percent. Consequently, the net increase in the productivity is only 14.5 percent. The productivity is about unchanged in the year 2010-2011. On the other hand, the productivity is declined by 13 percent in the period 2006-07 which is about evenly due to decline in technical efficiency and technological progress. In the period 2008-9, the productivity is declined by 13 percent mainly due to decline in technological progress. Similarly, the productivity is declined by 3 percent in the period 2011-2 due to decrease in technological progress by 15 percent. On a geometric average, the productivity growth for the sector is 1.3 percent.

\subsection{The Malmquist Index for Pharmaceutical Industries}

Table- 8 summarizes the Malmquist productivity change index and its components summary of firm means over the period 2006-2012. The results show that on a geometric average, the productivity of the pharmaceutical industry is increased by 1.3 percent which is due to 4.1 percent increase in efficiency and 2.7 percent decrease in technical progress. The productivity is decreased in the case of seven industry and increased in the case of seven industry out of fourteen industry in the study. The industry-1's productivity is declined by 2 percent on the account 3 percent technological decline and 1 percent increase in technical efficiency. The maximum productivity gain is 17.4 percent by industry-10, and the maximum productivity loss is 12 percent by industry- 9 . The maximum efficiency gain is 26.2 percent by industry-10 and the maximum efficiency loss is 6 percent by industry-9. The highest technological progress is 11.4 percent achieved by industry-13 and the maximum loss is 7 percent by industry 4 .

Table 8. Malmquist index summary of firm means (2006-2012)

\begin{tabular}{cccccc}
\hline Industry & $\begin{array}{c}\text { Malmquist TFP } \\
\text { Index(Tfpch) }\end{array}$ & $\begin{array}{c}\text { Technical Efficiency } \\
\text { Change (Effch) }\end{array}$ & $\begin{array}{c}\text { Technological } \\
\text { Change (Techch) }\end{array}$ & $\begin{array}{c}\text { Pure Technical } \\
\text { Change (Pech) }\end{array}$ & $\begin{array}{c}\text { Scale Efficiency } \\
\text { Change (Sech) }\end{array}$ \\
\hline 1 & 0.979 & 1.010 & 0.970 & 1.036 & 0.975 \\
2 & 1.046 & 1.049 & 0.997 & 1.000 & 1.049 \\
3 & 1.053 & 1.110 & 0.949 & 1.119 & 0.992 \\
4 & 0.894 & 0.967 & 0.925 & 0.966 & 1.001 \\
5 & 0.953 & 1.000 & 0.953 & 1.000 & 1.000 \\
\hline
\end{tabular}




\begin{tabular}{cccccc}
\hline 6 & 1.047 & 1.065 & 0.983 & 1.000 & 1.065 \\
7 & 0.987 & 1.020 & 0.967 & 1.005 & 1.015 \\
8 & 0.969 & 0.989 & 0.979 & 1.000 & 0.989 \\
9 & 0.884 & 0.936 & 0.945 & 0.972 & 0.963 \\
10 & 1.174 & 1.262 & 0.930 & 1.187 & 1.064 \\
11 & 1.092 & 1.096 & 0.996 & 1.081 & 1.014 \\
12 & 1.075 & 1.118 & 0.961 & 1.171 & 0.955 \\
13 & 1.109 & 0.995 & 1.114 & 0.999 & 0.996 \\
14 & 0.958 & 1.000 & 0.958 & 1.000 & 1.000 \\
\hline G. Mean & 1.013 & 1.041 & 0.973 & 1.036 & 1.005 \\
\hline
\end{tabular}

Source: Author's calculations.

Note. All indexes are geometric averages.

\subsection{Leverage \& Productivity}

Table 8 shows that the productivity of the seven industries: industry $2,3,6,10,11,12, \& 13$ are increased over the period 2006-2012. The productivity of the seven industries: industry $1,4,5,7,8,9, \& 14$ are decreased over the period 2006-2012. At this stage, the leverage ratios are computed separately to investigate whether leverage contributed in the productivity growth. Table $9 \& 10$ shows that the average total debt ratios of the growth industries are 8.13 percent, 5.77 percent, and 4.94 percent for the year 2007, 2008, and 2009 respectively whereas the average total debts ratios of the declined industries are 20.27 percent, 18.11 percent, 12.91 percent for the year 2007, 2008, and 2009 respectively. The total debt ratios for the productivity declined firms are substantially higher than those of the productivity growth industries.

Table 9. Productivity growth industry debt ratios

\begin{tabular}{cccc}
\hline Year & Short-term & Long-term & Total Debts \\
\hline 2007 & 5.649 & 0.054 & 8.131 \\
2008 & 4.551 & 0.040 & 5.769 \\
2009 & 3.719 & 0.016 & 4.939 \\
2010 & 4.098 & 0.016 & 5.169 \\
2011 & 8.277 & 0.142 & 13.626 \\
2012 & 8.728 & 0.331 & 13.500 \\
\hline
\end{tabular}

Source: Author's calculations.

Note. All means are geometric averages.

However, the average total productivity ratios for the year 2010, 2011, \& 2012 for productivity growth industries are 5.17 percent, 13.63 percent and 13.50 percent respectively and the average total productivity ratios for the year $2010,2011, \& 2012$ for productivity declined industries are 4.54 percent, 4.89 percent and 4.34 percent respectively. Clearly, the leverage ratios are substantial lower for the productivity declined industries than those of productivity growth industries.

Table 10. Productivity declined industry debt ratios

\begin{tabular}{cccc}
\hline Year & Short-term & Long-term & Total Debts \\
\hline 2007 & 5.642 & 7.289 & 20.273 \\
2008 & 4.286 & 1.743 & 18.105 \\
2009 & 1.424 & 1.259 & 12.908 \\
2010 & 0.855 & 2.449 & 4.536 \\
2011 & 3.707 & 0.403 & 4.889 \\
2012 & 2.617 & 0.119 & 4.337 \\
\hline
\end{tabular}

Source: Author's calculations.

Note: All means are geometric averages. 
Thus the leverage ratio of the productivity growth industry are lower for the year 2007, 2008, and 2009 and higher for the year 2010, 2011, and 2012 than those of the productivity declined industry. As a trend, the productivity growth industries having an increasing trend of financial leverage and the productivity declined industries having a decreasing financial leverage ratios.

4.5 The Malmquist Productivity Indices and the Standard Measures of Corporate Performance (ROA, ROE, EPS, $R O S \& O C F A$ )

Table-11 shows the correlation coefficients between the Malmquist Productivity Index \& its components and the standard measures of corporate performance: Return on Assets (ROA, defined as net income divided by total assets), Return on shareholder's Equity (ROE, defined as net income divided by total shareholder's equity), Earning per Share (EPS, defined as net income divided by no. of outstanding shares), Return on Sales (ROS, defined as net income divided by net sales), Return per Employee (RPE, defined as net income divided by total number of employees), and Operating cash flow to total Assets (OCFA, defined as operating cash flow divided by total assets). The information represented by the Malmquist productivity change index and its components and the standard measures of corporate performance are completely different since the correlation coefficients are very small and hence insignificant. Thus the two types of corporate performance proxy: the Malmquist productivity change index and its components and the standard measures of corporate performance present different aspects of corporate performance.

Table 11. The correlation coefficients between the malmquist productivity index and the standard measures of corporate performance (ROA, ROE, EPS, ROS \& OCFA)

\begin{tabular}{cccccc}
\hline $\begin{array}{c}\text { Standard } \\
\text { Measures }\end{array}$ & $\begin{array}{c}\text { Malmquist } \\
\text { TFP Index }\end{array}$ & $\begin{array}{c}\text { Technical } \\
\text { Efficiency Change }\end{array}$ & $\begin{array}{c}\text { Technological } \\
\text { Change }\end{array}$ & $\begin{array}{c}\text { Pure Technical } \\
\text { Change }\end{array}$ & $\begin{array}{c}\text { Scale Efficiency } \\
\text { Change }\end{array}$ \\
\hline ROA & 0.105 & -0.042 & -0.072 & -0.115 & 0.083 \\
ROE & -0.069 & -0.083 & -0.065 & -0.072 & -0.049 \\
EPS & -0.012 & 0.033 & 0.065 & -0.061 & 0.151 \\
ROS & 0.224 & -0.007 & 0.152 & -0.036 & 0.038 \\
OCFA & 0.283 & -0.047 & 0.119 & -0.091 & 0.054 \\
\hline
\end{tabular}

Source: Author's calculations.

\section{Conclusions and the Future Research Directions}

This study report presents a report on the study-productivity growth, efficiency change and technical progress of pharmaceutical sector in Bangladesh. The study shows that the productivity growth is low because of two reasons: productivity is declined in the case of 50 percent of the sample times and 50 percent of the sample industries. The productivity growth would be substantially higher if the productivity of all sample industry and all sample time would be kept increasing. The industry should identify the causes of the productivity decline and should adapt the necessary measures in order to increase the total productivity. In addition, this study shows that the Malmquist productivity index \& its component and the traditional measures of corporate performance represent different aspects of corporate performance.

Hope that this study established a useful basis for the future researcher in the field. Based on this study, future research agendas are as follows.

(a) More comprehensive research, by including more samples in time and number of the industry and by using the research design of this study, should be conducted in future on the year every year in order to identify productivity change index, and reasons of productivity changes for the managerial decision making.

(b) Further research should be conducted, by including more samples in time and number of the industry and by using the research design of this study, in order to check one of the research findings-the Malmquist productivity change index and its components and the standard measures of corporate performance measure different aspects of corporate performance. In other words, it will be significant to see the relationship between the Malmquist productivity change index \& its components and the standard measures of the corporate performance.

(c) In addition, research should be conducted, by including more samples in time and number of the industry and by using the research design of this study, to check the dependence of the leverage on the Malmquist productivity change index and its components and the dependence of Malmquist productivity change index \& its components on the leverage by considering the Malmquist productivity change index and its components as the 
proxy of corporate performance in order to add new knowledge with the existing knowledge about the effect of leverage on the firm performance and the effect of firm performance on the leverage.

(d) Finally, this research design should be extended to the other sectors: textile, food and allied products, engineering, pharmaceuticals and chemicals, tannery \& leather, information technology, fuel and energy, ceramic and cement of the economy in order to make better productivity management decisions in the sectors. The relationship between the debt ratio and the Malmquist index \& its components of a sector should be compared with the other sectors to develop in-depth understanding. Furthermore, to determine the dependence of the leverage on the Malmquist productivity change index \& its components and the dependence of the Malmquist productivity change index $\&$ its components on the leverage by treating the Malmquist productivity change index and its components as the proxy of corporate performance. The results of one sector should be compared with the other sectors for developing understanding in the sectors.

\section{Acknowledgements}

This paper is based on Chapter 3 of my YNU dissertation. My Ph.D supervisor, Professor Hiroshi Morita and Professor Akira Higashida provided invaluable guidance and advice. The scholarship from Otsuka Toshimi Scholarship Foundation, Osaka, Japan is gratefully acknowledged. Thanks to my mother-Aysha Rashid, the source of all inspirations to conduct the Ph.D thesis. I am very grateful to the co-supervisors of my dissertation: Professor Katsumasa Nishide, \& Associate Professor Yuki Itoh of Department of Business Administration, YNU and to the examiners of my dissertation: Professor Tohru Inoue, \& Associate Professor Masataka Suzuki of department of economic, YNU. The supports from staffs of Department of Business Administration-Hiromi Diamond and Takashi Kuroiwa and Students Support Division-Keiko Tsuiya and Ikegawa Manami are also significant assistances to me in conducting this research.

\section{References}

Banker, R. D., Charnes, A., \& Cooper, W. W. (1984). Some Models for Estimating Technical and Scale Inefficiencies in Data Envelopment Analysis. Management Science, 30(9), 1078-1092. http://dx.doi.org/10.1287/mnsc.30.9.1078

Belasco, K. S. (1990). Bank Productivity: Improving Performance by Managing Non-Interest Expense. Rolling Meadows, Illinois: Bankers Publishing Company.

Berger, A. N., \& Bonaccorsi di Patti, E. (2006). Capital Structure and Firm Performance: A New Approach to Testing Agency Theory and an Application to Banking Industry. Journal of Banking \& Finance, 30, 1065-1102. http://dx.doi.org/10.1016/j.jbankfin.2005.05.015

Caves, D. W., Christensen, L. R., \& Diewert, W. E. (1982). Multilateral Comparisons of Output, Input, and Productivity Using Superlative Index Numbers. Economic Journal, Royal Economic Society, 92(365), 73-86. http://dx.doi.org/10.2307/2232257

Charnes, A., Cooper, W. W., \& Rhodes, E. (1978). Measuring the Inefficiency of Decision Making Units. European Journal of Operational Research, 2, 429-444. http://dx.doi.org/10.1016/0377-2217(78)90138-8

Christopher, W. F., \& Thor, C. G. (1993). Handbook for Productivity Measurement and Improvement. Portland, Oregon: Productivity Press.

Coelli, T., Rao, P., \& Battese, G. E. (1998). An Introduction to Efficiency and Productivity Analysis. Boston: Kluwer Academic Publishers. Chapter 10. http://dx.doi.org/10.1007/978-1-4615-5493-6_10

Färe, R., Grosskopf, S., Lindgren, B., \& Roos, P. (1989). Productivity Developments in Swedish Hospitals: A Malmquist Output Index Approach. Department of Economics. Discussion Paper No 89-3, Southern Illinois University; Illinois, Carbondale. In A. Charnes, W. W. Cooper, A. Y. Lewin, \& L. S. Seiford (Eds.), Data Envelopment Analysis: Theory, Methodology and Applications. Amsterdam: Kluwer Academic Publisher. http://dx.doi.org/10.1007/978-94-011-0637-5

Färe, R., Grosskopf, S., Norris, M., \& Zhang, Z. (1994). Productivity Growth, Technical Progress and Efficiency Change in Industrialized Countries. American Economic Review, 84(1), 66-83.

Farrell, M. J. (1957). The Measurement of Productive Efficiency. The Journal of Royal Statistical Society, 120, 253-281. http://dx.doi.org/10.2307/2343100

Grifell-Tatje, E., \& Lovell, C. A. K. (1997). The Sources of Productivity Change in Spanish Banking. European Journal of Operational Research, 98, 364-380. http://dx.doi.org/10.1016/s0377-2217(96)00353-0

Kendrick, J. W. (1993). Productivity-Why It Matters-How It's Measured. Handbook for Productivity Measurement 
and Improvement. Portland, Oregon: Productivity Press.

Kirikal, L. (2005). Productivity, the Malmquist Index and the Empirical Study of Banks in Estonia. Ph.D Thesis, Tallinn Technical University Press. http://digi.lib.ttu.ee/archives/2006/2006-07/1153225915.PDF

Lin, W., Liu, C., \& Chu, C. (2005). Performance Efficiency Evaluation of the Taiwan's Shipping Industry: An Application of Data Envelopment Analysis (Vol. 5, pp. 467-476). Proceedings of the Eastern Asia Society for Transportation Studies. Retrieved from http://www.easts.info/on-line/proceedings_05/467.pdf

Malmquist, S. (1953). Index Numbers and Indifference Surfaces. Trabajos de Estadistica, 4, 209-242. http://dx.doi.org/10.1007/bf03006863

Margaritis, D., \& Psillaki, M. (2010). Capital Structure, Equity Ownership and Firm Performance. Journal of Banking \& Finance, 34, 621-632. http://dx.doi.org/10.1016/j.jbankfin.2009.08.023

Mlima, A. P. (1999). Dissertation: Four Essays on Efficiency and Productivity in Swedish Banking. Economiska Studier, Göteborgs Universitet.

Mostafa, M. (2007). Benchmarking Top Arab Banks' Efficiency through Efficient Frontier Analysis. Industrial Management \& Data Systems, 107(6), 802-823. http://dx.doi.org/10.1108/02635570710758734

Shephard, R. W. (1970). Theory of Cost and Production Functions. Princeton: Princeton University Press.

Smith, F. W. (1993). $Q=P$ : A New Management Paradigm (pp. 1-7). Handbook for Productivity Measurement and Improvement, Portland, Oregon: Productivity Press.

Sumanth, D. J. (1998). Total Productivity Management: A Systemic and Quantitative Approach to Compete in Quality, Price and Time. Boca Raton, Florida: St. Lucie Press.

\section{Copyrights}

Copyright for this article is retained by the author(s), with first publication rights granted to the journal.

This is an open-access article distributed under the terms and conditions of the Creative Commons Attribution license (http://creativecommons.org/licenses/by/3.0/). 